\title{
Rarely reported dinoflagellates of the genera Ceratium, Gloeodinium, Histioneis, Oxytoxum and Prorocentrum (Dinophyceae) from the open southeast Pacific Ocean
}

\author{
Dinoflagelados raramente citados de los géneros Ceratium, Gloeodinium, Histioneis, Oxytoxum y \\ Prorocentrum (Dinophyceae) en aguas abiertas del Pacífico sur-oriental \\ Fernando Gómez ${ }^{1}$, Hervé Claustre ${ }^{2,3}$ and Sami Souissi ${ }^{4}$ \\ ${ }^{1}$ Laboratoire d'Océanographie Physique et de Biogéochimie, CNRS UMR 6535, Centre d'Océanologie de Marseille, \\ Université de la Méditerranée, 163 Avenue de Luminy, Case 901, 13288 Marseille, France \\ ${ }^{2}$ UPMC Univ. Paris 06, UMR 7093, Laboratoire d'Océanographie de Villefranche, \\ Quai de la Darse, 06230 Villefranche-sur-Mer, France \\ ${ }^{3}$ CNRS, UMR 7093, LOV, 06230 Villefranche-sur-Mer, France \\ ${ }^{4}$ Laboratoire d'Océanologie et de Géosciences, Station Marine de Wimereux, Université des Sciences et \\ Technologies de Lille-Lille1, 28 avenue Foch, BP 80, 62930 Wimereux, France
}

fernando.gomez@fitoplancton.com

\begin{abstract}
Resumen.- Se ilustran y brevemente describen dinoflagelados raramente citados de los géneros Ceratium, Gloeodinium, Histioneis, Oxytoxum y Prorocentrum procedentes de un transecto de $\sim 8000 \mathrm{~km}$ entre el archipiélago de las Islas Marquesas y las costas chilenas. Se han encontrado diecinueve especies del género Oxytoxum y siete especies de Histioneis. Se proporcionan por primera vez microfotografías de Histioneis hyalina, $H$. cf. pulchra y un espécimen identificado como Histiophysis sp., un género que no había sido citado desde su descripción original. Más allá de los típicos especímenes unicelulares de Prorocentrum, se describe un comportamiento colonial en Prorocentrum dentatum que presentaba células alineadas. Colonias de pares de células elipsoidales o esféricas embebidas en una matriz hialina se han adscrito a Gloeodinium marinum. Ceratium lanceolatum se encuentra por primera vez en el Pacífico Sur desde su descripción original. Se proporcionan microfotografías de Ceratium carnegiei, C. divaricatum y C. lanceolatum.
\end{abstract}

Palabras clave: Exuviaella, Histiophysis, fitoplancton, protistas, Pyrrhophyta

\section{Introduction}

The studies on the dinoflagellate composition in the southeast Pacific Ocean are mainly restricted to the coast of South America (Hermosilla 1973a, Muñoz \& Avaria 1980, Ochoa \& Gómez 1997), and the archipelagos of Galápagos and Juan Fernández (Marshall 1972, Hermosilla 1973b). In contrast, the dinoflagellates of the open waters of the southeast Pacific are one of the least investigated in the world's oceans. The Albatross Expedition (1904-5) occupied stations in the open

\begin{abstract}
Rarely reported dinoflagellates of the genera Ceratium, Gloeodinium, Histioneis, Oxytoxum and Prorocentrum from a $\sim 8000 \mathrm{~km}$ transect between the Marquesas Islands Archipelago and the Chilean coast are briefly described and illustrated. Nineteen species of the genus Oxytoxum and seven species of the genus Histioneis were identified to species level. Photographic records of Histioneis hyalina and $H$. cf. pulchra are for the first time reported. One specimen ascribed to Histiophysis sp., a genus never reported since the first description, is illustrated. Beyond the singlecell specimens of Prorocentrum, a colonial behavior was observed. A small species, identified as Prorocentrum dentatum, was encountered forming rows. Colonies of pairs of ellipsoidal or sphaerical cells embedded in a hyaline matrix have been ascribed to Gloeodinium marinum. Ceratium lanceolatum is for the first time reported in the South Pacific Ocean since the first description. Photographic records of Ceratium carnegiei, C. divaricatum and C. lanceolatum are reported.
\end{abstract}

Key words: Exuviaella, Histiophysis, phytoplankton, protist, Pyrrhophyta southeast Pacific. Based on net samples, Kofoid described numerous new thecate dinoflagellates in his elaborated monographs (Kofoid 1907, Kofoid \& Michener 1911, Kofoid \& Adamson 1911, Kofoid \& Skogsberg 1928, Kofoid \& Adamson 1933). The results of the Carnegie Expedition (1928-9) in the subtropical southeast Pacific were restricted to large unarmoured dinoflagellates of the order Peridiniales, especially the genus Ceratium (Graham 1942, Graham \& Bronikovsky 1944). Steemann Nielsen (1934) also investigated the genus Ceratium based on materials from the Dana Expedition (1928-30). 
Rampi, from samples of the Dana Expedition and other cruises in the tropical Pacific, described several new dinoflagellates (Rampi 1948, 1950, 1952). Balech (1962) investigated the dinoflagellates from the Downwind Expedition (1957-8). These studies were based on material collected with coarse net hauls, and often restricted to surface waters. Hasle (1960) constituted an exception because she investigated the phytoplankton composition based on bottle samples at three stations in the central equatorial Pacific.

Recent studies in the high-nutrient low-chlorophyll region of the central and eastern equatorial Pacific were accompanied of scarce detailed studies on the dinoflagellate composition, often only identified at suprageneric levels (Chavez \& Buck 1990). Iriarte \& Fryxell (1995) listed species of dinoflagellates from the central equatorial Pacific and Hardy et al. (1996) reported a few dinoflagellates identified at the genus level from the surface of the South Pacific Gyre. Despite its oceanographic interest, very little is known about the dinoflagellate composition in the open southeast Pacific.

Within this context, a cruise along a transect of $\sim 8000$ $\mathrm{km}$ from the Marquesas Is. Archipelago to the Chilean coasts provided the opportunity to observe numerous species of dinoflagellates that have been rarely reported in the literature. Previous studies were focused on unarmoured dinoflagellates (Gómez 2006, 2007a, Gómez \& Furuya 2007). This study illustrates and briefly describes the records of the genera Gloeodinium Bouquaheux, Histioneis Stein, Histiophysis Kofoid \& Michener and Oxytoxum Stein as well as the most interesting taxa of the genera Ceratium Schrank and Prorocentrum Ehrenberg from the open southeast Pacific.

\section{Material and methods}

Samples were collected during the BIOSOPE (Biogeochemistry and Optics South Pacific Experiment) cruise on board R/V L'Atalante from the Marquesas Is. to the coast of Chile off Concepción (26 October-12 December 2004) (Fig. 1). One hundred samples from 14 stations were collected by Niskin bottles between 5 and $270 \mathrm{~m}$ depth. These were preserved with acidified Lugol's solution and stored at $5^{\circ} \mathrm{C}$. Samples of $500 \mathrm{~mL}$ were concentrated via sedimentation in glass cylinders. The top $450 \mathrm{~mL}$ of sample was slowly siphoned off with smallbore tubing during 6 days. The remaining $50 \mathrm{~mL}$ of concentrate, representing $500 \mathrm{~mL}$ whole water, was then settled in composite settling chambers. The entire chamber was scanned at $200 \times$ magnification with an IX71 inverted microscope equipped with an Olympus digital camera (Olympus, Tokyo, Japan). Each specimen was photographed and measured at $400 \times$ magnification with Olympus DP70-BSW software.

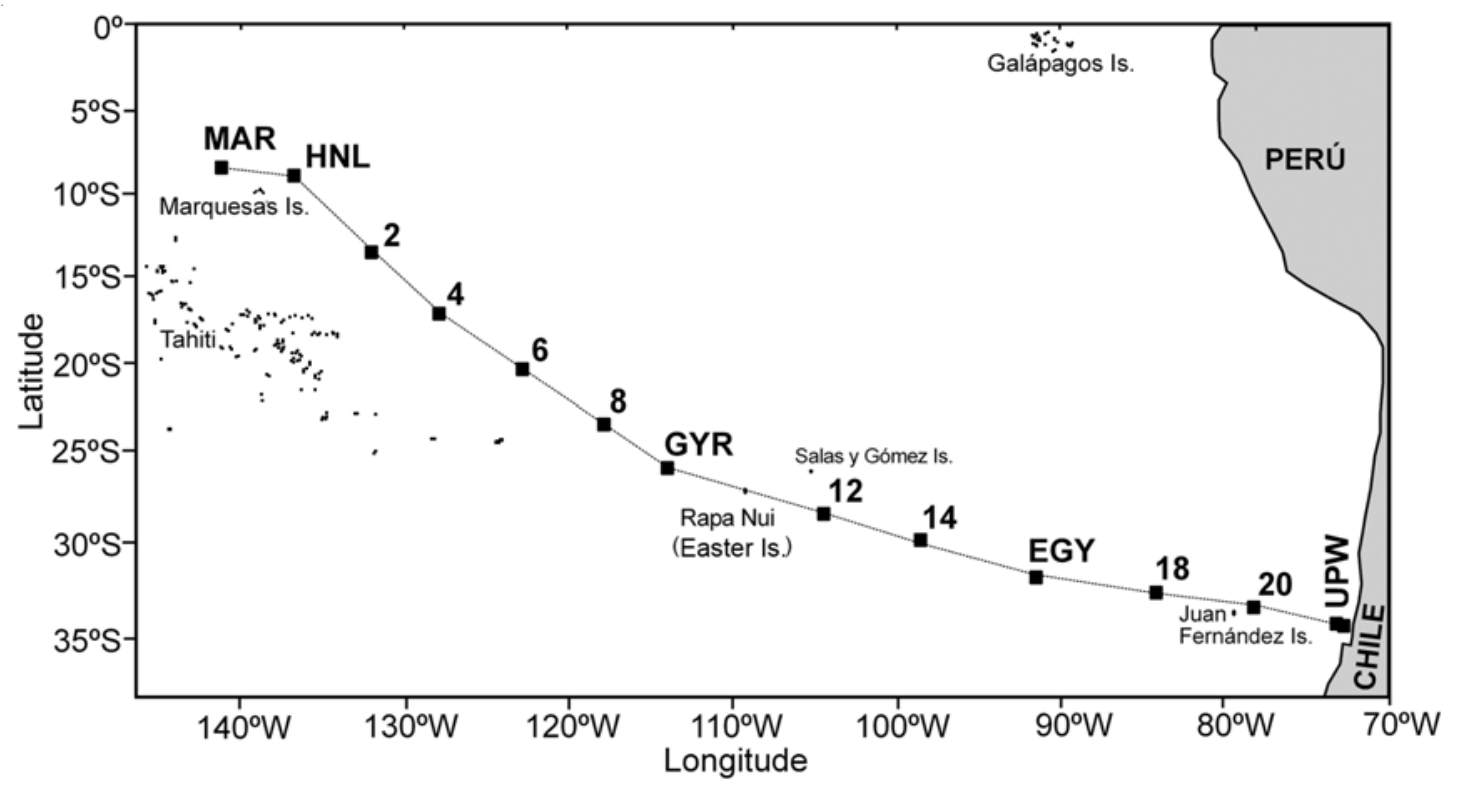

Figure 1

Map of the sampling stations occupied (solid squares) in the southeast Pacific Ocean

Mapa de las estaciones de muestreo, señaladas por cuadrados, en el Pacífico sur-oriental 


\section{Results}

\section{Oxytoxum}

Oxytoxum was one of the most ubiquitous dinoflagellate genera in the open waters of the southeast Pacific. A total of 19 species were identified and other specimens were not identified at the species level (Table 1). Each species is briefly described and illustrated (Figs. 2-38).

The type species, O. scolopax, showed an epitheca with a small domed structure with a spine onto the top. Specimens of $\sim 70 \mu \mathrm{m}$ in length were in good agreement with the original description (Figs. 6, 7). Other very elongated $(\sim 120 \mu \mathrm{m}$ long) specimens were also ascribed to O. scolopax (Figs. 4-5). Several specimens were also closed $O$. scolopax, although they did not show the bladderlike swelling at the base of the antapical spine that characterized $O$. scolopax. The epitheca had the shape of a long, drawn-out cone with slightly concave sides that tapered to an antapical spine (Figs. 2-3). These specimens with a robust appearance in comparison to the type species were ascribed to O. longiceps (Figs. 2-3). The possible synonymy between Oxytoxum sceptrum (Stein) Schröder and $O$. longiceps needs to be investigated.

Another specimen of $\sim 60 \mu \mathrm{m}$ in length was in agreement with the original description of $O$. challengeroides (Fig. 8). Other specimen showed a biconical shape, tapering sharply at apex and antapex, with the widest dimension at the cingulum (Fig. 9). The species O. subulatum Kofoid and O. milneri Murray \& Whitting were characterized by pointed apex, often long and tapered into asymmetrical point often long. The specimen in Fig. 9 showed intermediate characteristics between $O$. milneri and $O$. diploconus. It has been tentatively identified as $O$. diploconus based on the consideration that the apex was shorter than in O. milneri (Fig. 9).

Other medium size species were twice as long as broad (Figs. 10-11). The cingulum showed a displacement of about one cingulum width, deeply excavated, and showed striae at right angle to the margins of the hypotheca (Figs. 10-11). Two taxa, O. tesselatum and O. elegans agreed to this description. Oxytoxum michaelsarsii Gaarder, a tentative synonym of $O$. tesselatum, is characterized by a hypotheca with convex sides anteriorly becoming slightly concave toward the antapex. At first sight, the main difference between $O$. tesselatum and $O$. elegans was the length of apical spine that it is shorter in $O$. tesselatum. The specimen in Fig. 10 has been ascribed to O. elegans, despite the apical horn is more developed than in the original description. The specimen with a less pointed epitheca has been ascribed to O. tesselatum (Fig. 11).
Other specimens showed sub-circular cell body with an obtusely angled apex and a sub-acute antapex. The epitheca was low and lacking the acute apical spines, the cingulum was deep, and displaced one width and the length $\sim 50 \mu \mathrm{m}$ (Figs. 12-14). One of the specimens showed the hypotheca nearly straight (Fig. 12) with a shape intermediate between O. reticulatum (Stein) Schütt and $O$. belgicae Meunier. Oxytoxum frenguellii was more robust than $O$. reticulatum. The epitheca of $O$. areolatum Rampi showed a concave outline, whereas the epitheca was nearly straight in the other species. The intraspecific morphological variability of the species is unknown, and it is difficult the separation of these species. Oxytoxum latum Gaarder and $O$. frenguellii may be conspecific. Oxytoxum frenguellii may be also a morphotype of $O$. reticulatum. The specimen of the figure 12 has been ascribed to $O$. cf. frenguellii.

Another specimens of $\sim 50 \mu \mathrm{m}$ in length showed a higher displacement of the cingulum than in $O$. frenguellii and the hypotheca was bent (Figs. 13-14). Oxytoxum cristatum Kofoid is characterized by the bent hypotheca, and the epitheca also bent in the opposite direction of the hypotheca. Oxytoxum compressum has an elongated and curve hypotheca. These morphological characters strictly did not fit with the specimens in Figs. 13 and 14. They have been ascribed to $O$. curvicaudatum. In contrast, $O$. constrictum is one of the most distinctive species of the genus due to the constriction in the hypotheca. The specimens of $O$. constrictum observed in this study showed a variable length (Figs. 15-16).

One specimen with a scarcely marked cingulum, and the epitheca apparently encapsulated has not been identified. It is uncertain whether it corresponded to an Oxytoxum species (Fig. 17). Oxytoxum curvatum was characterized by a blunt apical region, and a long curved hypotheca (Fig. 18). Another species showed elongated hypotheca bent in the extreme with a pointed spine (Fig. 19). The hypotheca was conical with a straight outline, and a spine. The general appearance resembled a robust specimen of the species O. elongatum Wood. The length of the specimen of the Fig. 19 was $70 \mu \mathrm{m}$, whereas the size of $O$. elongatum in the original description was higher than 150 $\mu \mathrm{m}$. Oxytoxum longum was also longer and the epitheca was rounder than in the specimen in Fig. 19.

Fig. 20 illustrate a specimen of swollen outline, and it cannot be discarded that it may constitute an unarmoured dinoflagellate such as Amphidinium sphenoides Wulff. The specimen has been tentatively identified as $O$. cf. parvum, although its cingulum was not well marked. Other specimens showed morphology 


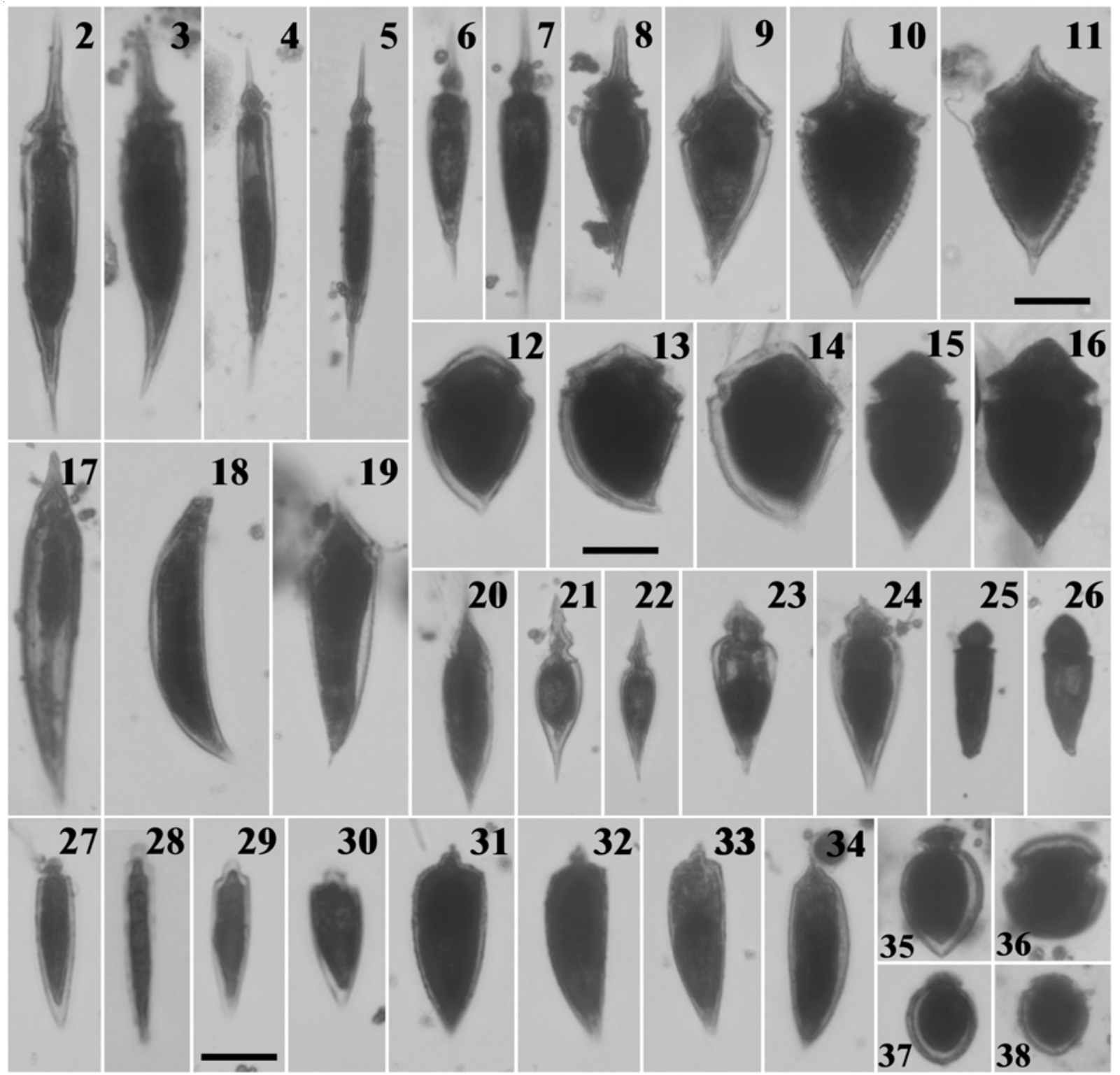

Figures 2-38

Photomicrographs of Oxytoxum spp. and two unarmoured dinoflagellates, bright field optics. See Table 1 for the location of the records. (2-3) $O$. longiceps. (4-5) Elongated cell of $O$. scolopax. (6-7) O. scolopax. (8) O. challengeroides. (9) $O$. diploconus. (10) O. elegans. (11) O. tesselatum. (12) Oxytoxum cf. frenguellii. (13-14) O. curvicaudatum. (15-16) O. constrictum. (17) Tentative Oxytoxum sp. (18) O. curvatum. (19) Elongated Oxytoxum sp. (20) Tentative Oxytoxum sp. (2122) O. parvum. (23-24) O. turbo. (25-26) Unidentified Amphidinium-like cells. (27-28) Oxytoxum cf. longum. (29-30) O. variabile. (31-32) O. caudatum. (33-34) O. cf. caudatum. (35) O. cf. laticeps. (36) O. cf. sphaeroideum. (37) O. cf. globosum. (38) $O$. cf. crassum. All the micrographs at the same magnification. Scale bar of $20 \mu \mathrm{m}$

Microfotografías de Oxytoxum spp. y dos dinoflagelados atecados, óptica de campo claro. Véase la localización de los registros en la Tabla 1. (2-3) O. longiceps. (4-5) Célula alargada de O. scolopax. (6-7) O. scolopax. (8) O. challengeroides. (9) O. diploconus.

(10) O. elegans. (11) O. tesselatum. (12) Oxytoxum cf. frenguellii. (13-14) O. curvicaudatum. (15-16) O. constrictum. (17) Tentativamente Oxytoxum sp. (18) O. curvatum. (19) Célula alargada de Oxytoxum sp. (20) Tentativamente Oxytoxum sp. (21-22) O. parvum. (23-24) O. turbo. (25-26) Células no identificadas cercanas a Amphidinium. (27-28) Oxytoxum cf. longum. (29-30) O. variabile. (31-32) O. caudatum. (33-34) O. cf. caudatum. (35) O. cf. laticeps. (36) O. cf. sphaeroideum. (37) O. cf. globosum. (38) $O$. cf. crassum. Todas las fotografías a la misma escala. Barra de escala de $20 \mu \mathrm{m}$ 
Table 1

\section{Geographic coordinates (latitude, longitude, depth) of the records of dinoflagellates from the southeast Pacific Ocean illustrated in the figures 2-79}

Coordenadas geográficas (latitud, longitud, profundidad) de los registros de dinoflagelados del Pacífico sur-oriental ilustrados en las figuras 2-79

\begin{tabular}{|c|c|c|c|c|}
\hline Taxon & $\begin{array}{l}\text { Latitude } \\
\text { South }\end{array}$ & $\begin{array}{c}\text { Longitude } \\
\text { West }\end{array}$ & $\begin{array}{l}\text { Depth } \\
\text { (m) }\end{array}$ & Figure \\
\hline Oxytoxum longiceps Schiller & $28^{\circ} 31^{\prime}$ & $104^{\circ} 18^{\prime}$ & 210 & 2 \\
\hline Oxytoxum longiceps Schiller & $31^{\circ} 52^{\prime}$ & $91^{\circ} 24^{\prime}$ & 5 & 3 \\
\hline Elongated Oxytoxum scolopax Stein & $33^{\circ} 21^{\prime}$ & $78^{\circ} 06^{\prime}$ & 25 & 4 \\
\hline Elongated Oxytoxum scolopax Stein & $30^{\circ} 02^{\prime}$ & $98^{\circ} 23^{\prime}$ & 160 & 5 \\
\hline Oxytoxum scolopax Stein & $13^{\circ} 32^{\prime}$ & $132^{\circ} 07^{\prime}$ & 100 & 6 \\
\hline Oxytoxum scolopax Stein & $28^{\circ} 31^{\prime}$ & $104^{\circ} 18^{\prime}$ & 180 & 7 \\
\hline Oxytoxum challengeroides Kofoid & $23^{\circ} 32^{\prime}$ & $117^{\circ} 52^{\prime}$ & 210 & 8 \\
\hline Oxytoxum diploconus Stein & $13^{\circ} 32^{\prime}$ & $132^{\circ} 07^{\prime}$ & 5 & 9 \\
\hline Oxytoxum elegans Pavillard & $26^{\circ} 01$ & $114^{\circ} 01^{\prime}$ & 120 & 10 \\
\hline Oxytoxum tesselatum Stein & $8^{\circ} 23^{\prime}$ & $141^{\circ} 14^{\prime}$ & 50 & 11 \\
\hline Oxytoxum cf. frenguellii Rampi & $30^{\circ} 02^{\prime}$ & $98^{\circ} 23^{\prime}$ & 5 & 12 \\
\hline Oxytoxum curvicaudatum Kofoid & $31^{\circ} 52^{\prime}$ & $91^{\circ} 24^{\prime}$ & 125 & 13 \\
\hline Oxytoxum curvicaudatum Kofoid & $28^{\circ} 31^{\prime}$ & $104^{\circ} 18^{\prime}$ & 165 & 14 \\
\hline Oxytoxum constrictum (Stein) Bütschli & $33^{\circ} 21^{\prime}$ & $78^{\circ} 06^{\prime}$ & 40 & 15 \\
\hline Oxytoxum constrictum (Stein) Bütschli & $30^{\circ} 02^{\prime}$ & $98^{\circ} 23^{\prime}$ & 200 & 16 \\
\hline Tentative Oxytoxum sp. & $33^{\circ} 21^{\prime}$ & $78^{\circ} 06^{\prime}$ & 40 & 17 \\
\hline Oxytoxum curvatum (Kofoid) Kofoid & $17^{\circ} 13^{\prime}$ & $127^{\circ} 58^{\prime}$ & 5 & 18 \\
\hline Elongated Oxytoxum sp. & $32^{\circ} 42^{\prime}$ & $84^{\circ} 04^{\prime}$ & 120 & 19 \\
\hline Tentative Oxytoxum sp. & $32^{\circ} 42^{\prime}$ & $84^{\circ} 04^{\prime}$ & 60 & 20 \\
\hline Oxytoxum parvum Schiller & $9^{\circ}$ & $136^{\circ} 51^{\prime}$ & 5 & 21 \\
\hline Oxytoxum parvum Schiller & $17^{\circ} 13^{\prime}$ & $127^{\circ} 58^{\prime}$ & 40 & 22 \\
\hline Oxytoxum turbo Kofoid & $20^{\circ} 27^{\prime}$ & $122^{\circ} 53^{\prime}$ & 220 & 23 \\
\hline Oxytoxum turbo Kofoid & $9^{\circ}$ & $136^{\circ} 51^{\prime}$ & 100 & 24 \\
\hline Unidentified Amphidinium-like cell & $23^{\circ} 32^{\prime}$ & $117^{\circ} 52^{\prime}$ & 100 & 25 \\
\hline Unidentified Amphidinium-like cell & $26^{\circ} 01$ & $114^{\circ} 01^{\prime}$ & 270 & 26 \\
\hline Oxytoxum cf. longum Schiller & $33^{\circ} 21^{\prime}$ & $78^{\circ} 06^{\prime}$ & 15 & 27 \\
\hline Oxytoxum cf. longum Schiller & $31^{\circ} 52^{\prime}$ & $91^{\circ} 24^{\prime}$ & 5 & 28 \\
\hline Oxytoxum variabile Schiller & $13^{\circ} 32^{\prime}$ & $132^{\circ} 07^{\prime}$ & 100 & 29 \\
\hline Oxytoxum variabile Schiller & $13^{\circ} 32^{\prime}$ & $132^{\circ} 07^{\prime}$ & 20 & 30 \\
\hline Oxytoxum caudatum Schiller & $8^{\circ} 23^{\circ}$ & $141^{\circ} 14^{\prime}$ & 40 & 31 \\
\hline Oxytoxum caudatum Schiller & $9^{\circ}$ & $136^{\circ} 51^{\prime}$ & 60 & 32 \\
\hline Oxytoxum cf. caudatum Schiller & $9^{\circ}$ & $136^{\circ} 51^{\prime}$ & 40 & 33 \\
\hline Oxytoxum cf. caudatum Schiller & $30^{\circ} 02^{\prime}$ & $98^{\circ} 23^{\prime}$ & 5 & 34 \\
\hline Oxytoxum cf. laticeps Schiller & $33^{\circ} 21^{\prime}$ & $78^{\circ} 06^{\prime}$ & 100 & 35 \\
\hline Oxytoxum ef. sphaeroideum Schiller & $33^{\circ} 21^{\prime}$ & $78^{\circ} 06^{\prime}$ & 5 & 36 \\
\hline Oxytoxum cf. globosum Kofoid & $17^{\circ} 13^{\prime}$ & $127^{\circ} 58^{\prime}$ & 85 & 37 \\
\hline Oxytoxum ef. crassum Schiller & $8^{\circ} 23^{\circ}$ & $141^{\circ} 14^{\prime}$ & 20 & 38 \\
\hline Histioneis cf. striata Kofoid \& Michener & $31^{\circ} 52^{\prime}$ & $91^{\circ} 24^{\prime}$ & 40 & 39 \\
\hline Histioneis joergensenii Schiller & $30^{\circ} 02^{\prime}$ & $98^{\circ} 23^{\prime}$ & 75 & 40 \\
\hline Histioneis sp. (dorsal view) & $32^{\circ} 42^{\prime}$ & $84^{\circ} 04^{\prime}$ & 75 & 41 \\
\hline Histioneis cf. crateriformis Stein & $20^{\circ} 27^{\prime}$ & $122^{\circ} 53^{\prime}$ & 170 & 42 \\
\hline Histioneis cf. crateriformis Stein & $31^{\circ} 52^{\prime}$ & $91^{\circ} 24$ & 40 & 43 \\
\hline Histioneis cf. crateriformis Stein & $31^{\circ} 52^{\prime}$ & $91^{\circ} 24^{\prime}$ & 190 & 44 \\
\hline cf. Histiophysis sp. & $33^{\circ} 21^{\prime}$ & $78^{\circ} 06^{\prime}$ & 60 & 45 \\
\hline Histioneis cleaveri Rampi & $28^{\circ} 31^{\prime}$ & $104^{\circ} 18^{\prime}$ & 80 & 46 \\
\hline Histioneis cleaveri Rampi & $9^{\circ}$ & $136^{\circ} 51^{\prime}$ & 40 & 47 \\
\hline Histioneis cleaveri Rampi & $9^{\circ}$ & $136^{\circ} 51^{\prime}$ & 30 & 48 \\
\hline
\end{tabular}




\begin{tabular}{|c|c|c|c|c|}
\hline Histioneis cf. pulchra Kofoid & $32^{\circ} 42^{\prime}$ & $84^{\circ} 04^{\prime}$ & 105 & $49-50$ \\
\hline Histioneis longicollis Kofoid & $31^{\circ} 52^{\prime}$ & $91^{\circ} 24^{\prime}$ & 60 & 51 \\
\hline Histioneis hyalina Kofoid \& Michener & 823 & $141^{\circ} 14^{\prime}$ & 40 & 52 \\
\hline Prorocentrum sp 1. (pear-shaped) & $20^{\circ} 27^{\prime}$ & $122^{\circ} 53^{\prime}$ & 190 & 53 \\
\hline Prorocentrum cf. compressum (hyaline) & $33^{\circ} 21^{\prime}$ & $78^{\circ} 06^{\prime}$ & 40 & 54 \\
\hline Prorocentrum sp2. (small) & $13^{\circ} 32^{\prime}$ & $132^{\circ} 07^{\prime}$ & 100 & 55 \\
\hline Prorocentrum cf. hhathymum Loeblich III, Sherley \& R.J. Schmidt & $33^{\circ} 21^{\prime}$ & $78^{\circ} 06^{\prime}$ & 5 & 56 \\
\hline Prorocentrum cf. mathymum Loeblich III, Sherley \& R.J. Schmidt & $31^{\circ} 52^{\prime}$ & $91^{\circ} 24^{\prime}$ & 40 & 57 \\
\hline Prorocentrum dentatum Stein & $9^{\circ}$ & $136^{\circ} 51^{\circ}$ & 30 & $58-60$ \\
\hline Gloeodinium marimum (ellipsoidal cells) & $8^{\circ} 23$ & $141^{\circ} 14^{\prime}$ & 20 & $61-62$ \\
\hline Gloeodinium marimm (sphaerical cells) & $28^{\circ} 31^{\prime}$ & $104^{\circ} 18^{x}$ & 80 & $63-64$ \\
\hline Ceratium cf. lineatum (Ehrenberg) Cleve & $9^{\circ}$ & $136^{\circ} 51^{\times}$ & 15 & 65 \\
\hline $\begin{array}{l}\text { Ceratium divaricatum var. balechii Hernández-Becerril } \\
\text { (=C. balechii Meave, Okolodkov \& Zamudio) }\end{array}$ & $8^{\circ} 23^{\prime}$ & $141^{\circ} 14^{x}$ & 40 & 66 \\
\hline Ceratium divaricatum var. balechii Hernández-Becerril & $8^{\circ} 23^{\prime}$ & $141^{\circ} 14^{x}$ & 60 & 67 \\
\hline Ceratium divaricatum var. balechii Hernández-Becerril & $8^{\circ} 23^{\prime}$ & $141^{\circ} 14^{\prime}$ & 50 & 68 \\
\hline Ceratium divaricatum var. balechii Hemández-Becerril & $8^{\circ} 23^{\prime}$ & $141^{\circ} 14^{*}$ & 10 & 69 \\
\hline Ceratium divaricatum var. balechii Hemández-Becerril & $34^{\circ} 38^{\prime}$ & $72^{\circ} 28^{\prime}$ & 5 & 70 \\
\hline C. divaricatum (Lemmermann) Kofoid var. divaricatum & $33^{\circ} 21^{\prime}$ & $78^{\circ} 06^{\prime}$ & 5 & 71 \\
\hline C. divaricatum (Lemmermann) Kofoid var. divaricatum & $33^{\circ} 21^{\prime}$ & $78^{\circ} 06^{\prime}$ & 5 & 72 \\
\hline Ceratium lanceolatum Kofoid & $33^{\circ} 21^{\prime}$ & $78^{\circ} 06^{\prime}$ & 40 & 73 \\
\hline Ceratium lanceolatum Kofoid & $33^{\circ} 21^{\prime}$ & $78^{\circ} 06^{\prime}$ & 40 & $74-75$ \\
\hline Ceratium carnegiei Graham \& Bronikowsky & $33^{\circ} 21^{\prime}$ & $78^{\circ} 06^{\prime}$ & 5 & $76-77$ \\
\hline Ceratium carnegiei Graham \& Bronikowsky & $8^{\circ} 23^{\prime}$ & $141^{\circ} 14^{\prime}$ & 20 & 78 \\
\hline Ceratium carnegiei Graham \& Bronikowsky & $8^{\circ} 23^{\prime}$ & $141^{\circ} 14^{7}$ & 40 & 79 \\
\hline
\end{tabular}

close to the species $O$. parvum, O. longiceps and $O$. sceptrum. According to the original descriptions, the length of $O$. longiceps and $O$. sceptrum were higher than $70 \mu \mathrm{m}$, while the specimens observed in this study were $30-50 \mu \mathrm{m}$ in length. Based on the size and the shape similarities, the specimens were in agreement with the description of $O$. parvum (Figs. 21-22). Another specimen showed a hemispherical epitheca with apparently a short spine. The hypotheca was long, swollen below the cingulum, and pointed at the base. These specimens were ascribed to $O$. turbo (Figs. 23-24). The anterior position of the cingulum of some elongated specimens of Oxytoxum may be confused with unarmoured dinoflagellates such as Amphidinium-like cells (Figs. 25-26).

Figs. 27-34 showed specimens with a minute epitheca compared with the longer, wider, and pointed hypotheca. The longer specimens have been ascribed to O. longum (Figs. 27-28), and the smaller ones with a hypotheca with wide shoulders were ascribed to O. variabile (Figs. 2930 ). The size of $O$. variabile was highly variable ranging from 15 to $30 \mu \mathrm{m}$ in length. The species O. caudatum showed a small domed epitheca, with small apical spine, and hypotheca with an acute antapex that may be centred (Fig. 31) or curved (Figs. 32-33). The contour of the hypotheca of $O$. caudatum did not show wider shoulders, and the antapex had a spine (Fig. 34). The species $O$. coronatum Schiller differed from O. caudatum on the occurrence of small spines in the epitheca that may be lost due to sample treatment. The occurrence of spines is a poor diagnostic character, and it cannot be discarded the conspecifity of both taxa.

More difficult is the identification of small Oxytoxum species with ovate hypotheca (Figs. 35-38). The use of nets for sampling probably results in severe underrepresentation of these small species. Based on light microscopy, the delimitation among the species $O$. sphaeroideum, O. ovum Gaarder, O. pachyderme Schiller, O. crassum, O. minutum Rampi and Oxytoxum viride Schiller was difficult. Oxytoxum laticeps $(=O$. mediterraneum Schiller) was one of the most distinctive species of this group (Fig. 35). The hypotheca was relatively large, roundly lenticular with a pointed antapex with convex sides, and the length was $30 \mu \mathrm{m}$ (Fig. 35). Another specimen with a round cell body and nearly median cingulum has been ascribed to $O$. cf. sphaeroideum (Fig. 36). The specimen of the Fig. 37 has been tentatively identified as $O$. cf. globosum (Fig. 37), and the specimen of the Fig. 38 as $O$. cf. crassum.

\section{Histioneis and Histiophysis}

Only twelve specimens of Histioneis, ascribed to seven species, were encountered. One specimen was devoid of 
cell contents, and another specimen was a transition form between Dinophysis Ehrenberg and Histioneis (Table 1). All the records are here illustrated (Figs. 39-52). One specimen, with a cherry-shaped body, the fission $\mathrm{rib}\left(\mathrm{R}_{2}\right)$, and the third rib $\left(\mathrm{R}_{3}\right)$ forming two loops, was ascribed to $H$. cf. striata (Fig. 39). Histioneis joergensenii showed a sub-rotund cell body, the $\mathrm{R}_{2}$ bending posteriorly, anastomising with $\mathrm{R}_{3}$ about halfway (Fig. 40). Another specimen related to the $H$. longicollis-group appeared attached to an aggregate (Fig. 41). Three specimens have been ascribed to $H$. crateriformis, being closer, if not conspecific, with $H$. reticulata Kofoid (Figs. 42-44). The hypotheca was semicircular, and the cingulum broad with $\mathrm{R}_{3}$ ventrally deflected. The development of the left sulcal list varies among the specimens (Figs. 43-44) with the $\mathrm{R}_{3}$ well developed in the larger specimen (Fig. 44).

Another specimen showed intermediate characteristics between Dinophysis and Histioneis (Fig. 45). The left sulcal list was very developed as usual in species of Histioneis such as H. tubifera Böhm in Schiller. The cell body was circular and convex on the top. The shape of the cell body and scarce development of the cingular chamber was unusual in Histioneis. In contrast to Histioneis, the specimen did not harbor unicellular cyanobacteria in the scarce developed cingular chamber. This specimen has been ascribed to the genus Histiophysis Kofoid \& Skogsberg (Fig. 45).

The eastern tropical Pacific Ocean is the type locality of numerous species of Histioneis. Several specimens corresponded to Histioneis cleaveri, described by Rampi (1952) from the central equatorial Pacific $\left(3^{\circ} \mathrm{S}, 175^{\circ} \mathrm{W}\right)$. Two specimens that matched with the initial description were encountered in the proximities of the Marquesas Is. Archipelago (Figs. 47-48) and one specimen in the Humboldt Current (Fig. 46). The morphology of other specimen coincided with the original description of $H$. longicollis (Fig. 51). Another specimen, devoid of cell contents, corresponded to $H$. hyalina (Fig. 52). The largest specimen of Histioneis observed in this study (120 $\mu \mathrm{m}$ long) showed a saddle-shaped cell body, higher dorsally (Figs. 49-50). The specimen resembled $H$. cymbalaria Stein as illustrated in Stein (1883, plate 22, figure 7). Stein apparently illustrated three different species under the name $H$. cymbalaria, and it is difficult to establish to which illustration corresponded to $H$. cymbalaria. Stein did not provide information on the size and the type locality of the specimens. The dorsal view of the specimen did not agree with the dorsal view of $H$. cymbalaria in Stein (1883) (Fig. 50). The specimen has been tentatively identified as $H$. cf. pulchra (Figs. 49-50).

\section{Prorocentrum}

The species of the genus Prorocentrum were nearly absent in the severe oligotrophic waters of the South Pacific Gyre, except the ubiquitous $P$. rostratum Stein. A few specimens, all lacking the apical spine, were encountered in the more eutrophic conditions, near the Marquesas Is. Archipelago and the Humboldt Current (Table 1). The most extended morphology was an ellipsoidal shape, scarcely marked anterior region, and lacking the anterior spine. Most of the specimens resembled benthic species of Prorocentrum (Figs. 53-57), although it should be noted that the sea floor was deeper than $4000 \mathrm{~m}$ depth in the sampling stations.

One specimen showed hyaline pyriform valves of 70 $\mu \mathrm{m}$ in length (Fig. 53). Another specimen with highly hyaline valves of $60 \mu \mathrm{m}$ long and $50 \mu \mathrm{m}$ wide has been tentatively ascribed to Prorocentrum cf. compressum (Fig. 54). Another of the specimens showed smaller size ( 30 $\mu \mathrm{m}$ long) (Fig. 55). Two larger specimens of Prorocentrum were encountered near the Juan Fernández Archipelago (Fig. 56) and the Humboldt Current at 2000 $\mathrm{km}$ off Chile (Fig. 57). The dimensions were $55 \mu \mathrm{m}$ long and $33 \mu \mathrm{m}$ wide. The cells appeared more pigmented in the anterior part. These specimens resembled Prorocentrum cf. rhathymum (Figs. 56-57).

One Prorocentrum species from the surrounding waters of the Marquesas Is. Archipelago showed up to seven cells in a line (Fig. 58). These rows of cells may be longer, although the labile junctions may be fragmented due to sample treatment. The anterior extreme of one specimen was in contact with the posterior part of the other specimen (Figs. 59-60). The shape of the specimens showed a variable degree of elongation. The cell size was 18-20 $\mu \mathrm{m}$ long and 8-10 $\mu \mathrm{m}$ wide (Fig. 60). These specimens have been ascribed to Prorocentrum dentatum (Figs. 58-60).

\section{Gloeodinium}

A colony of two pairs of ellipsoidal cells embedded in mucilage of $\sim 200 \mu \mathrm{m}$ long and $\sim 150 \mu \mathrm{m}$ wide was encountered offshore the Marquesas Is. Archipelago (Fig. 61). Each cell was $40 \mu \mathrm{m}$ long and $25 \mu \mathrm{m}$ wide (Figs. 61-62). Other jelly of $\sim 300 \mu \mathrm{m}$ long and $\sim 200 \mu \mathrm{m}$ wide containing 10 pairs of spherical cells was encountered in the offshore boundary of the Humboldt Current (Figs. 63-64). Each cell showed a spherical hyaline capsule of 21-24 $\mu \mathrm{m}$ in diameter. It showed a more irregular contour inside the capsule. The central part of the capsule of $\sim 12-$ $13 \mu \mathrm{m}$ was irregularly circular, and highly pigmented, resembling the nucleus of a dinoflagellate. These 


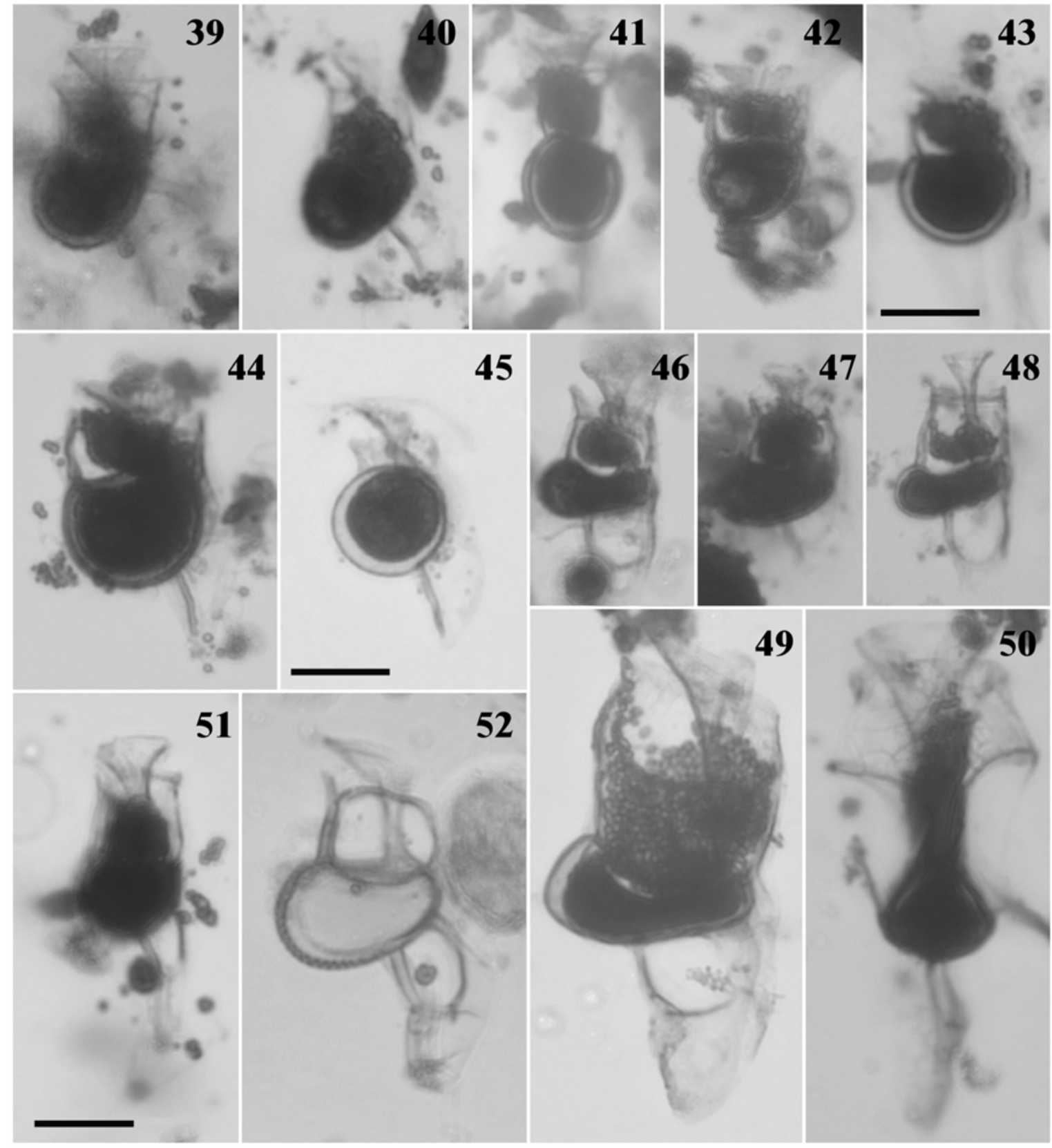

Figures 39-52

Photomicrographs of Histioneis spp. and Histiophysis sp. in right lateral view, except figures 41 and 50 in dorsal view, bright field optics. See Table 1 for the location of the records. (39) H. cf. striata. (40) H. joergensenii. (41) Histioneis sp. (dorsal view). (42-44)

$H$. cf. crateriformis. (45) Tentative Histiophysis sp. (46-48) H. cleaveri. (49-50) $H$. cf. pulchra in lateral and dorsal views, respectively. (51) $\mathrm{H}$. longicollis. (52) $\mathrm{H}$. hyalina. All the micrographs at the same magnification. Scale bar of $20 \mu \mathrm{m}$

Microfotografias de Histioneis spp. y Histiophysis sp. en vista lateral derecha, excepto las figuras 41 y 50 en vista dorsal, óptica de campo claro. Véase la localización de los registros en la Tabla 1. (39) H. cf. striata. (40) H. joergensenii. (41) Histioneis sp. (vista dorsal). (4244) $H$. cf. crateriformis. (45) Tentativamente identificado como Histiophysis sp. (46-48) H. cleaveri. (49-50) H. cf. pulchra en vista lateral y dorsal. (51) $H$. longicollis. (52) $H$. hyalina. Todas las fotografías a la misma escala. Barra de escala de $20 \mu \mathrm{m}$ 


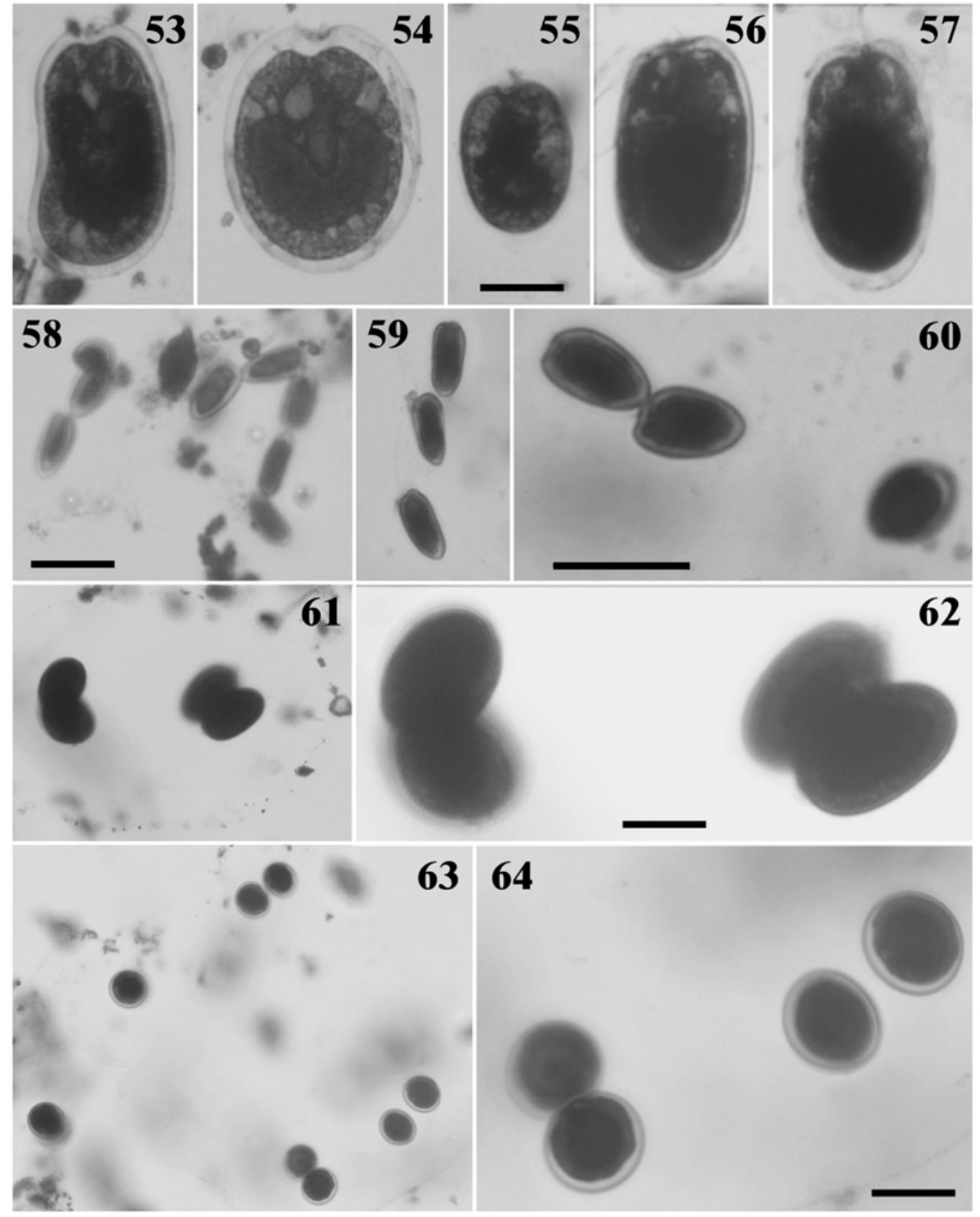

Figures 53-64

Photomicrographs of Prorocentrum spp. and Gloeodinium marinum, bright field optics. See Table 1 for the location of the records. (53) Prorocentrum sp1. (54) Prorocentrum cf. compressum. (55) Prorocentrum sp2. (56-57) Prorocentrum cf. rhathymum. (58-60) Prorocentrum dentatum. (61-62) Ellipsoidal cells of Gloeodinium marinum. (63-64) Sphaerical cells of G. marinum. Figs. 53-59, 62, 64 at the same magnification. Scale bar of $20 \mu \mathrm{m}$

Microfotografías de Prorocentrum spp. y Gloeodinium marinum, óptica de campo claro. Véase la localización de los registros en la Tabla 1. (53) Prorocentrum sp1. (54) Prorocentrum cf. compressum. (55) Prorocentrum sp2. (56-57) Prorocentrum cf. rhathymum. (58-60) Prorocentrum dentatum. (61-62) Células elipsoidales de Gloeodinium marinum. (63-64) Células esféricas de G. marinum. Figs. 53-59, 62, 64 a la misma escala. Barra de escala de $20 \mu \mathrm{m}$ 


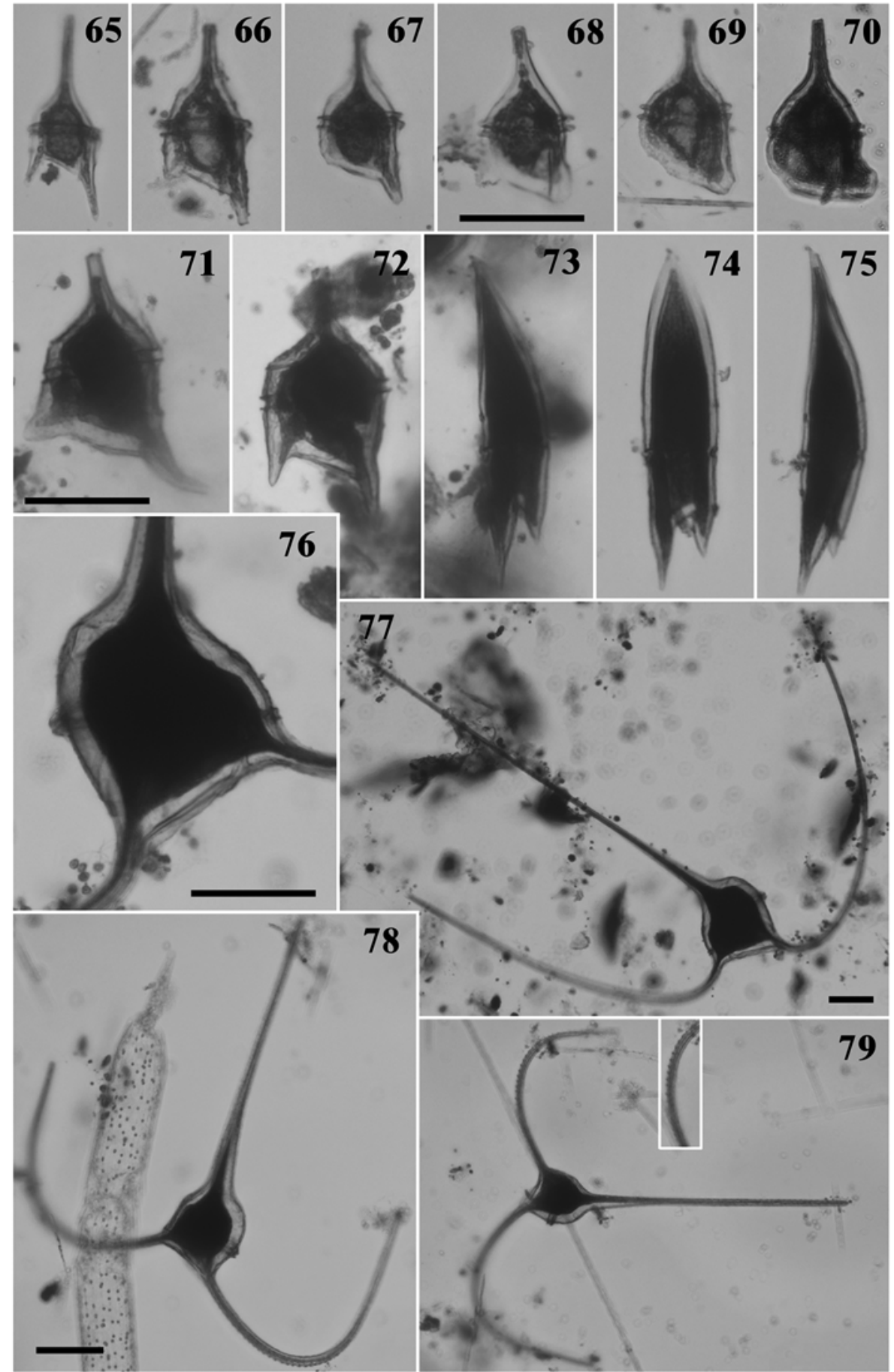

Figures 65-79

Photomicrographs of Ceratium spp., bright field optics. See Table 1 for the location of the records. (65) C. cf. lineatum. (66-70). C. divaricatum var. balechii (=C. balechii). (71-72) C. divaricatum var. divaricatum. (73-75) C. lanceolatum. (76-79) C. carnegiei. Figs. 65-75 at the same magnification. Scale bar of $50 \mu \mathrm{m}$

Microfotografías de Ceratium spp., óptica de campo claro. Véase la localización de los registros en la Tabla 1. (65) C. cf. lineatum. (66-70) C. divaricatum var. balechii (=C. balechii). (71-72) C. divaricatum var. divaricatum. (73-75) C. lanceolatum.

(76-79) C. carnegiei. Figs. 65-75 a la misma escala. Barra de escala de $50 \mu \mathrm{m}$ 
observations coincided with stages of the life cycle of Gloeodinium marinum described by Bouquaheux (1971) (Figs. 63-64).

\section{Ceratium}

A total of 30 species of the genus Ceratium were recorded (see checklist in Gómez et al. 2007). This study focuses on the species $C$. divaricatum due to its assumed high morphological variability, and another two species, $C$. lanceolatum and $C$. carnegiei that are rarely reported in the literature (Table 1).

The specimens of Ceratium divaricatum showed a high morphological variability or they may represent more than one species (Figs. 66-72). One of these forms was described as a separate species under the name $C$. balechii by Meave et al. (2003) or as the variety $C$. divaricatum var. balechii by Hernández-Becerril \& Alonso-Rodríguez (2004). In the equatorial upwelling region near the Marquesas Is. Archipelago, numerous specimens with a triangular epitheca, a very short apical horn (Figs. 66-70), and the right antapical horn absent (Figs. 67, 69) or reduced (Figs. 66, 68) were encountered. The right antapical horn tended to be more than developed than the left one (Figs. 66-70). The right antapical horns were directed posteriorly (Fig. 66) or laterally in one specimen from the Chilean coastal upwelling (Fig. 70). In this study, Figs. 66-69 corresponded to specimens of the same station near the Marquesas Is. Archipelago. The cell body of the species $C$. lineatum was closer to the shape of these specimens. However, the records of $C$. cf. lineatum did not co-occur with these specimens. Ceratium cf. lineatum was smaller in size (40 $\mu \mathrm{m}$ wide, Fig. 65) than these specimens assigned to $C$. divaricatum var. balechii (=C. balechii) (Figs. 66-70).

Several robust and larger specimens with an irregular contour of the epitheca and the apical horn truncate were encountered in the proximities of the Juan Fernández Archipelago (650 km off Chile) (Figs. 71-72). One of the specimens showed the right antapical more developed than the left one, and both forming an angle of $\sim 45$ degrees with respect the cingulum (Fig. 71). Another specimen showed the antapical horns directed laterally (Fig. 72). These two specimens, with a robust and coarse appearance, showed the outline of the epitheca more irregular has been ascribed to $C$. divaricatum var. divaricatum (Figs. 71-72).

Ceratium lanceolatum is an extremely rare taxon with highly distinctive lanceolate shape. Two specimens were collected at $40 \mathrm{~m}$ depth from the same sample in the proximities of the Juan Fernández Archipelago (Figs. 73$75)$. Both specimens were similar in shape and size (130 $\mu \mathrm{m}$ long and $28 \mu \mathrm{m}$ wide) (Figs. 73-75).
Ceratium carnegiei is a distinctive species, large ( $>400 \mu \mathrm{m}$ long) and robust. It was described from the tropical southeast Pacific Ocean. Despite these characteristics that facilitate the collection by net hauls, the records of this species has been scarce. The most distinctive feature is the relatively large volume of the epitheca compared to its nearest relatives (Figs. 76-77). The specimens showed small spines on the posterior proximal regions of the antapical horns (Figs. 78-79). Only three specimens were observed. Two specimens were encountered near the Marquesas Is. Archipelago (Figs. 78-79) and other specimen in the Humboldt Current near the Juan Fernández Archipelago (Figs. 76-77).

\section{Discussion}

The tropical and subtropical open waters of the southeast Pacific Ocean are one of the least investigated of the world's oceans. The historical Expeditions in the southeast Pacific Ocean collected samples from the surface or vertical net hauls (Kofoid \& Michener 1911, Kofoid \& Skogsberg 1928, Kofoid \& Adamson 1933, Graham \& Bronikovsky 1944, Rampi 1948, 1950, 1952, Balech 1962). These coarse net hauls under-represented the smaller species, and destroyed other large delicate species or colonial forms. One of the most useful and detailed study in the region was carried out by Hasle (1960) that investigated the phytoplankton from bottle samples at three stations in the central equatorial Pacific at $145^{\circ} \mathrm{W}, 0-2^{\circ} \mathrm{N}$.

\section{Oxytoxum}

The studies on the genus Oxytoxum have been relatively scarce despite the high diversity in the open warm ocean. The differentiation of the genera Corythodinium Loeblich Jr. \& Loeblich III and Oxytoxum is still unresolved. Overall, nineteen species were recorded and other specimens were not identified at the species level (Table 1). Hasle (1960) reported 8 species: Oxytoxum caudatum, O. curvatum, O. laticeps, O. longum, O. milneri Murray \& Whitting, O. sceptrum, O. scolopax and O. variabile. All these species are illustrated in this study, although $O$. cf. milneri sensu Hasle is here ascribed to O. diploconus. The species $O$. subulatum or $O$. milneri were characterized by a pointed apex, often long, and tapered into an asymmetrical point. Hasle (1960) illustrated $O$. cf. milneri, but her specimen was more robust and the apex more pointed than in the original description of $O$. milneri. Balech (1988) illustrated a slightly premedian cingulum for $O$. diploconus and median cingulum in Corythodinium cf. milneri. There was not data on the size of $O$. diploconus in the original description (Stein 1883). In this study it has been considered the record as O. diploconus (Fig. 9) instead of $O$. cf. milneri as reported 
by Hasle (1960). It cannot be discarded the conspecifity of O. milneri, O. subulatum and O. diploconus.

According to Hasle (1960) the most abundant species was $O$. variabile that reached 4000 cells $\mathrm{L}^{-1}$ which size ranged from 15 to $30 \mu \mathrm{m}$ in length. Rampi (1952) from a close location reported the larger species $O$. elegans, $O$. sceptrum, O. scolopax, O. sphaeroideum and $O$. tesselatum, whereas $O$. variabile was absent. Hasle (1960) was based on bottles samples, whereas Rampi was based on net sampling that may under-represent the small size species such as $O$. variabile. The epithet of the species is representative of the high variability in size and shape assumed in O. variabile, and even may be confused with unarmoured dinoflagellates such as Amphidinium Claparède \& Lachmann. The species $O$. gracile has been regarded as a synonym of $O$. variabile (Hasle 1960). Oxytoxum gracile showed wider shoulders in the hypotheca than O. variabile. The specimens in this study were closer to the original description of $O$. gracile (Figs. 29-30). Oxytoxum variabile and O. gracile, described from the cold waters of the shallow Adriatic Sea, showed a short apical spine in the epitheca that was absent in the specimens illustrated by Hasle (1960). From an ecological point of view, the type locality of both taxa strongly differed from the environmental conditions of the central Pacific Ocean. It is uncertain whether $O$. variabile was the same species in these two contrasted environments. After Hasle (1960) this taxon has been reported as $O$. variabile in the equatorial Pacific Ocean (Desrosièrs 1971, Iriarte \& Fryxell 1995). The species O. gladiolus Schiller had a similar shape, and the epitheca had not an apical short spine, and it was described from warm waters of the Atlantic Ocean (Stein 1883), and reported near the Hawaii Is. Archipelago (Lemmermann 1905). In this study, following previous studies, the specimens have been ascribed to O. variabile. Further research is needed to clarify the identity of this taxon.

In the central equatorial Pacific, Iriarte \& Fryxell (1995) listed O. caudatum, O. curvatum, O. laticeps, O. milneri, O. cf. sceptrum, O. scolopax, O. tonollii Rampi, $O$. turbo and O. variabile. Oxytoxum tonollii was also observed in this study, although it is considered an inverted specimen of the genus Amphidoma Stein (Taylor 1976). From the North Pacific Gyre, Venrick (1982) listed Oxytoxum curvatum, O. curvicaudatum, $O$. constrictum, O. elegans, O. laticeps, O. adriaticum Schiller, O. globosum, O. longum, O. parvum, O. scolopax, O. cf. sphaeroideum, O. subulatum, $O$. turbo and $O$. variabile. Oxytoxum adriaticum strongly resembled one of the varieties of $O$. sphaeroideum described from the Hawaii Is. Archipelago (Lemmermann 1905).
One of the specimens of Oxytoxum showed a discontinuity in the outline of the epitheca (Fig. 13) that was illustrated by Balech (1988, plate 82, Fig. 8) under the name Corythodinium sp. This morphology was also illustrated by Wood (1968) for O. curvicaudatum. This study is the first to illustrate $O$. challengeroides since the initial description (Fig. 8). The specimen in Fig. 12 was more robust than $O$. areolatum, and less elongated than O. strophalatum Dodge \& Saunders. The specimen was ascribed to $O$. cf. frenguellii (Fig. 12).

\section{Histioneis}

Despite more than one hundred species of the genus Histioneis has been described, little is known about one of the most numerous dinoflagellate genera. The specimens are often refereed as Histioneis sp. in the literature due to the difficulties in the delimitation of the species (Gómez 2007b). Twelve specimens of Histioneis were encountered in this study. This is a scarce number of records when compared to other geographical areas. For example, Gómez (2005) found 17 of specimens a single seawater sample of $400 \mathrm{ml}$ from the North Philippine Sea. The records of Histioneis could be more numerous by using net sampling. However, smaller specimens may be under-represented and the delicate sulcal list may be damaged. From the twelve specimens encountered, four specimens were recorded in the upper 30-40 m depth, three specimens at 170-190 m depth, and two specimens of the same species appeared at 40 and $190 \mathrm{~m}$ depth at the same sampling station (Figs. 43-44). It is difficult to establish a clear pattern in the distribution of the genus Histioneis.

Histioneis cf. crateriformis and $H$. cleaveri were the most represented species (Table 1). Gómez (2005) tentatively found a specimen of $H$. cf. cleaveri in the western equatorial Pacific. This taxon was not cited since the description by Rampi (1952) in the southern equatorial Pacific. These new observations confirm the validity of $H$. cleaveri. More doubts appeared with $H$. crateriformis, a taxon of difficult identification due to the scarce development of the left sulcal list. It is difficult to establish a separation from close relatives such as $H$. reticulata and $H$. pachypus Böhm in Schiller and also $H$. mediterranea Schiller (Gómez 2007b).

Stein (1883) reported three different lateral figures and one ventral view for $H$. cymbalaria. Later, Schiller (1933) described H. skogsbergii Schiller based on one of the lateral views, and the ventral view illustrated by Stein for H. cymbalaria. Kofoid \& Skogsberg (1928) considered other of the Stein's figures (plate 22, fig. 10) of $H$. cymbalaria very close to $H$. hyalina. This study is the first to report a photographic record of H. hyalina 
(Fig. 52). The specimen observed was devoid of cell content. This record showed that $H$. hyalina is a distinctive taxon, and different from $H$. cymbalaria sensu Stein. Other specimen identified as H. pulchra (49-50) was also close to one of the figures of $H$. cymbalaria by Stein (1883). Abé (1967) proposed H. pulchra as a synonym of $H$. mitchellana Murray \& Whitting. Abé considered that the figures of $H$. mitchellana by Kofoid \& Skogsberg (1928) also illustrated H. pulchra. Recently Gómez (2005) illustrated H. mitchellana. Histioneis mitchellana and $H$. pulchra should be regarded as separate species until further research.

\section{Prorocentrum}

Prorocentrum rostratum, a highly distinctive species, was the most ubiquitous Prorocentrum species in the open southeast Pacific. However, it resulted more difficult the identification of other species with an ovate shape and lacking spines, resembling benthic or epiphytic species of Prorocentrum. The net sampling may under-represent these Prorocentrum species. Based on net sampling, Rampi (1952) only listed Exuviaella compressa, E. lenticula Matzenauer and Prorocentrum rostratum. Based on bottles samples, Hasle (1960) recorded Exuviaella baltica Lohmann, E. compressa, P. obtusidens Schiller, $P$. rostratum, E. vaginula Stein and described the new species Exuviaella aequatorialis Hasle. Venrick (1982) listed Prorocentrum cf. compressum, P. dactylus, $P$. obtusidens, $P$. rostratum, $P$. cf. triestinum and $P$. vaginulum. Iriarte \& Fryxell (1995) listed Prorocentrum compressum, P. maximum, $P$. obtusidens and $P$. rostratum. Beyond the ubiquitous $P$. rostratum, the specimens lacking apical spine with oval shape in the open tropical Pacific Ocean have received the name of $P$. compressum. In the proximities of the region investigated by Hasle, Rampi (1952) and Iriarte \& Fryxell (1995) reported $P$. lenticulatum (Matzenauer) F.J.R. Taylor. Hasle (1960) described the new species Exuviaella aequatorialis with almost circular outline of $19 \mu \mathrm{m}$ in diameter, and two distinct notches in the flagellar pores. Dodge (1975) oversynonymized the species of the genus Prorocentrum, and erroneously proposed $E$. equatorialis as a synonym of $P$. balticum (Lohmann) Loeblich III, and P. lenticulatum as a synonym of $P$. compressum (Bailey) Abé ex Dodge. However, E. equatorialis should be considered as a synonym of $P$. lenticulatum.

A colonial behavior was observed in specimens encountered forming rows of cells (Figs. 58-60). The specimens were small (18-20 $\mu \mathrm{m}$ long, 8-10 $\mu \mathrm{m}$ wide), showing a different degree of elongation. The anterior part was asymmetrical, with one side more developed than the other one (Fig. 60). The junction among the specimen was weak, and this may be responsible of the lack in other studies due to the breakage using drastic methods such as net sampling. The illustration and description of P. maximum in Hasle (1960), also listed by Iriarte \& Fryxell (1995), coincided with single-cell specimens of the species observed forming rows in the central equatorial Pacific Ocean (Figs. 58-60). Dodge (1975) erroneously synonymized $P$. maximum and $P$. mexicanum Osorio-Tafall (Cortés-Altamirano \& SierraBeltrán 2003).

The morphology of the specimens of the figures 5860 was close to species reported as $P$. obtusidens in the central Pacific Ocean (Hasle 1960, Venrick 1982, Iriarte \& Fryxell 1995). According to Schiller (1933) the length of $P$. obtusidens was $36 \mu \mathrm{m}$, while the colonial specimens in this study were about one half of the length of $P$. obtusidens (Figs. 58-60). The shape of the specimens agrees with $P$. triestinum sensu Taylor (1976) that reported a smaller size than in the original description. Dodge (1975) and Hernández-Becerril et al. (2000) considered Prorocentrum obtusidens as a synonym of $P$. dentatum. Hernández-Becerril et al. (2000) illustrated a two-cell chain of $P$. dentatum of similar size to those in this study $(<20 \mu \mathrm{m}$ in length) (Fig. 60). From the year 2000 Prorocentrum dentatum has been observed to cause large blooms in Chinese coastal waters (Tang et al. 2006). This species, later named as Prorocentrum donghainese Lu, often showed 4-cell chains (Lu et al. 2005) as reported in this study (Figs. 58-59). Le Gall et al. (2008) have established cultures of Prorocentrum minimum (Pavillard) Schiller and P. dentatum from material collected during this cruise in the SE Pacific Ocean.

\section{Gloeodinium}

The colonies of Gloeodinium were first reported in the Atlantic Ocean as unidentified cysts by Schütt (1895). In the Sargasso Sea, an oligotrophic environment as the South Pacific Gyre, Gaarder (1954) illustrated tentative pairs of spherical cyst of dinoflagellates embedded in mucilage. Gaarder (1954) suggested a relation to the specimens of E. compressa embedded in mucilage that she also found. Hasle (1960) reported for Exuviaella compressa 'Four cells were found embedded in a jelly mass in the same way as depicted by Gaarder (1954)'. Two Norwegian researchers, Gaarder (1954) and Hasle (1960), by using similar methodology found cells ascribed to Prorocentrum embedded in mucilage from bottle samples of the sub-tropical Atlantic and the equatorial Pacific, respectively. Previous studies based on net hauls would easily destroy these delicate structures (Figs. 6164). These unidentified colonies also appeared in the western Mediterranean Sea (Margalef et al. 1954). In the 
French Mediterranean coast, Bouquaheux (1971) described these mucilaginous colonies of pairs of cells as a part of the life cycle of the new species Gloeodinium marinum. Taylor (1976) also reported colonies of Gloeodinium from the Indian Ocean, with no further records in the literature.

\section{Ceratium}

Most of the species of the genus Ceratium are large, robust, and easy collectable by using nets. Consequently Ceratium is one of the best known genera of dinoflagellates. The identification at the species level is relatively easy, although some species showed a high intraspecific morphological variability. The identification of the species of Ceratium is mainly based on the length and orientation of the horns and the delimitation between species and varieties may be difficult. Several species showed a pronounced phenomenon of dichotomy, and exuviations of the horns as described by Kofoid (1908) for $C$. divaricatum, often confused with C. dens Ostenfeld $\&$ Schmidt. The variety Ceratium divaricatum var. balechii proposed by Hernández-Becerril \& AlonsoRodríguez (2004) was previously described as the new species C. balechii Meave, Okolodkov \& Zamudio (Meave et al. 2003). This new species was defined based only on morphometric differences that may result insufficient for a highly variable taxon. HernándezBecerril \& Alonso-Rodríguez (2004) reported as diagnostic character that the base of the apical horn was continuous in the variety $C$. divaricatum var. divaricatum and well-defined in C. divaricatum var. balechii. In this study, the two tentative varieties of Ceratium divaricatum appeared in two geographically distant populations. Ceratium divaricatum var. balechii appeared in the Marquesas Is. Archipelago and the Chilean upwelling off Concepción, whereas the form $C$. divaricatum var. divaricatum was encountered in the offshore Humboldt Current. The morphology and size of the specimens of these separate populations were rather different to be considered as only varieties. The different morphological characteristics and geographical separation of the populations suggested that these varieties may be truly separate species. However, studies based on clone cultures and molecular phylogeny are needed to clarify the status of $C$. balechii.

Ceratium lanceolatum was described by Kofoid (1907) off Perú. This study is the first to report a photographic record of $C$. lanceolatum from the South Pacific. Hernández-Becerril (1988) reported this taxon from the Pacific coasts of México. Kofoid (1907) reported a transdiameter of 19-22 $\mu \mathrm{m}$ and a length of 95-122 $\mu \mathrm{m}$.
The length of the specimens from the Humboldt Current was similar to the original description off Perú, although the transdiameter was slightly wider (Figs. 73-75). Ceratium lanceolatum was absent in the extensive collections from the Dana Expedition by Steemann Nielsen (1934), Rampi (1952), neither from the Carnegie Expedition by Graham \& Bronikovsky (1944). After Kofoid, Gaarder (1954) found one specimen of $C$. lanceolatum in the tropical North Atlantic Ocean. She reported a transdiameter of $56 \mu \mathrm{m}$ and a length of 285 $\mu \mathrm{m}$. The specimen illustrated by Gaarder (1954) seems to be closer to C. schroeteri B. Schröder. Later Wood (1968) reported C. lanceolatum from the northern waters of Brazil. The length was 100-150 $\mu \mathrm{m}$ and the shape was similar to the original description.

Ceratium carnegiei is a large and distinctive species. This taxon was known from the tropical Indian Ocean (see references in Taylor 1976). Gaarder (1954) found one specimen in the tropical North Atlantic Ocean. Despite its high size and distinctive cell body shape, no further records of C. carnegiei have been reported in the Atlantic Ocean.

The decline of taxonomical studies in open ocean waters is responsible of that numerous species, even large and distinctive ones, were absent from the literature since decades. Numerous species are considered rare, although this is due to lack of studies where these species can be found.

\section{Acknowledgments}

F. G. is supported by a post-doctoral grant of the Ministerio Español de Educación y Ciencia \#2007-0213. We thank J. Ras for her collection assistance and R. Cortés Altamirano for his suggestions. This is a contribution of the BIOSOPE project of the LEFE-CYBER program.

\section{Literature cited}

Abé TH. 1967. The armoured Dinoflagellata: II. Prorocentridae and Dinophysidae C- Ornithocercus, Histioneis, Amphisolenia and others. Publications of the Seto Marine Biology Laboratory 15: 79-116.

Balech E. 1962. Tintinnoidea y Dinoflagellata del Pacífico según material de las expediciones Norpac y Downwind del Instituto Scripps de Oceanografía. Revista del Museo Argentino de Ciencias Naturales 'B. Rivadavia', Ciencias Zoológicas 7: 1-253.

Balech E. 1988. Los dinoflagelados del Atlántico Sudoccidental. Publicaciones especiales del Instituto Español de Oceanografía 1: 1-310. 
Bouquaheux F. 1971. Gloeodinium marinum nov. sp. Peridinien Dinocapsale. Archiv für Protistenkunde 113: 314-321.

Chavez FP \& KR Buck. 1990. Phytoplankton taxa in relation to primary production in the equatorial Pacific. Deep-Sea Research 37: 1733-1752.

Cortés-Altamirano R \& AP Sierra-Beltrán. 2003. Morphology and taxonomy of Prorocentrum mexicanum and reinstatement of Prorocentrum rhathymum (Dinophyceae). Journal of Phycology 39: 221-225.

Desrosières R. 1971. Quelques stations de phytoplancton entre les Iles Tuamotu et les Iles Marquises (Océan Pacifique Central). Cahiers O.R.S.T.O.M., série océanographique 9: 119-124.

Dodge JD. 1975. The Prorocentrales (Dinophyceae). II. Revision of the taxonomy within the genus Prorocentrum. Botanical Journal of the Linnaean Society 71: 103-125.

Gaarder KR. 1954. Dinoflagellateae from the 'Michael Sars' North Atlantic Deep-Sea Expedition 1910. Reports Scientific Results 'Michael Sars' North Atlantic Deep-Sea Expedition 1910, 2: 1-62.

Gómez F. 2005. Histioneis (Dinophysiales, Dinophyceae) from the western Pacific Ocean. Botanica Marina 48: 421-425.

Gómez F. 2006. The dinoflagellate genera Brachidinium, Asterodinium, Microceratium and Karenia in the open SE Pacific Ocean. Algae 21: 445-452.

Gómez F. 2007a. Nuevos registros del dinoflagelado Craspedotella Kofoid, 1905 (Dinophyceae: Noctilucales) en el Océano Pacífico. Revista de Biología Marina y Oceanografía 42: 83-87.

Gómez F. 2007b. Synonymy and biogeography of the dinoflagellate genus Histioneis (Dinophysiales: Dinophyceae). Revista de Biología Tropical 55: 459-477.

Gómez F \& K Furuya. 2007. Kofoidinium, Spatulodinium and other kofoidiniaceans (Noctilucales, Dinophyceae) in the Pacific Ocean. European Journal of Protistology 43: 115-124.

Gómez F, H Claustre, P Raimbault \& S Souissi. 2007. Two high-nutrient low-chlorophyll phytoplankton assemblages: the tropical central Pacific and the offshore Perú-Chile Current. Biogeosciences 4: 1101-1113.

Graham HW. 1942. Studies in the morphology, taxonomy, and ecology of the Peridiniales. Scientific Results Cruise VII 'Carnegie' 1928-1929. Biology 3: 1-129.

Graham HW \& N Bronikovsky. 1944. The genus Ceratium in the Pacific and north Atlantic Oceans. Scientific Results Cruise VII 'Carnegie' 1928-1929. Biology 5: 1-20.

Hardy J, A Hanneman, M Behrenfeld \& R Horner. 1996. Environmental biogeography of near-surface phytoplankton at the southeast Pacific Ocean. Deep-Sea Research I 43: 1647-1659.

Hasle GR. 1960. Phytoplankton and ciliate species from the tropical Pacific. Skrifter utgitt av Det Norske VidenskapsAkademi i Oslo. I. Matematisk-Naturvideskabelig klasse 2: $1-50$.

Hermosilla JG. 1973a. Contribución al conocimiento sistemático de los dinoflagelados y tintínidos del archipiélago de Juan Fernández. Boletín de la Sociedad de Biología de Concepción 46: 11-36.

Hermosilla JG. 1973b. Contribución al conocimiento sistemático de los dinoflagelados de la Bahía de Concepción, Chile. Gayana, Zoología 24: 1-149.

Hernández-Becerril DU. 1988. Especies de fitoplancton tropical del Pacífico Mexicano. II. Dinoflagelados y cianobacterias. Revista Latinoamericana de Microbiología 30: 187-196.

Hernández-Becerril DU, R Cortés Altamirano \& R Alonso. 2000. The dinoflagellate genus Prorocentrum along the coasts of the Mexican Pacific. Hydrobiologia 418: 111-121.

Hernández-Becerril DU \& R Alonso-Rodríguez. 2004. Study of the marine planktonic dinoflagellate Ceratium divaricatum (Dinophyceae), a confused and considerable variable species. Phycological Research 52: 346-354.

Iriarte JL \& GA Fryxell. 1995. Microplankton at the equatorial Pacific $\left(140^{\circ} \mathrm{W}\right)$ during the JGOFS EqPac Time Series studies: March to April and October 1992. DeepSea Research II 42: 559-583.

Kofoid CA. 1907. New species of dinoflagellates. Reports on the scientific results of the expedition to the Eastern Tropical Pacific. Museum of Comparative Zoology at Harvard College, Bulletin 50: 161-207.

Kofoid CA. 1908. Exuviation, autotomy and regeneration in Ceratium. University of California Publications in Zoology 4: 345-386.

Kofoid CA \& JR Michener. 1911. New genera and species of dinoflagellates. Museum of Comparative Zoology at Harvard College, Bulletin 54: 1-265.

Kofoid CA \& AM Adamson. 1911. New genera and species of dinoflagellates. Museum of Comparative Zoology at Harvard College, Bulletin 54: 267-302.

Kofoid CA \& T Skogsberg. 1928. The Dinoflagellata: the Dinophysoidea. Museum of Comparative Zoology at Harvard University, Memories 51: 1-708.

Kofoid CA \& AM Adamson. 1933. The Dinoflagellata: The family Heterodiniidae of the Peridinioidae. Museum of Comparative Zoology at Harvard University, Memories 54: 1-136. 
Le Gall F, F Rigaut-Jalabert, D Marie, L Garczarek, M Viprey, A Gobet \& D Vaulot. 2008. Picoplankton diversity in the South-East Pacific Ocean from cultures. Biogeosciences 5: 203-214.

Lemmermann E. 1899. Ergebnisse einer Reise nach dem Pacific (H. Schauinsland 1896-97). Planktonalgen. Abhandlungen Herausgegeben vom Naturwissenschaftlichen Verein zu Bremen 16: 313-398.

Lemmermann E. 1905. Die Algenflora der Sandwich-Inseln. Ergebnisse einer Reise nach dem Pacific, H. Schauinsland 1896-97. Engler's Botanische Jahrbücher 34: 607-663.

Lu D, J Gobel, Y Qi, J Zou, X Han, Y Gao \& Y Li. 2005. Morphological and genetic study of Prorocentrum donghaiense Lu from the East China Sea and comparison with some related Prorocentrum species. Harmful Algae 4: 493-505.

Margalef R, J Herrera, J Rodríguez-Roda \& MG Larrañeta. 1954. Plancton recogido por los laboratorios costeros, VIII. Fitoplancton de las costas de Castellón durante el año 1952. Publicaciones del Instituto de Biología Aplicada, Barcelona 17: 87-100.

Marshall HG. 1972. Phytoplankton composition in the southeastern Pacific between Ecuador and the Galápagos Islands (Archipiélago de Colón). Proceedings of the Biological Society of Washington 85: 1-38.

Meave del Castillo ME, ME Zamudio, YB Okolodkov \& IH Salgado. 2003. Ceratium balechii sp. nov. (Dinophyceae: Gonyaulacales) del Pacífico Mexicano. Hidrobiológica 13: 75-90.

Muñoz P \& S Avaria. 1980. Estudio taxonómico de los dinoflagelados tecados de la Bahía de Valparaíso. I. Género Ceratium. Revista de Biología Marina 17: 1-57.

Ochoa N \& O Gómez. 1997. Dinoflagelados del mar peruano como indicadores de masas de aguas durante los años 1982 a 1985. Boletín del Instituto del Mar del Perú 16: 1-60.
Rampi L. 1948. Sur quelques Péridiniens rares ou intéressants $\mathrm{du}$ Pacifique subtropical. Bulletin de l'Institut Océanographique, Monaco 937: 1-9.

Rampi L. 1950. Péridiniens rares ou nouveaux pour le Pacifique sud-Équatorial. Bulletin de l'Institut Océanographique, Monaco 974: 1-12.

Rampi L. 1952. Ricerche sul Microplancton di superficie del Pacifico tropicale. Bulletin de l'Institut Océanographique, Monaco 1014: 1-16.

Schiller J. 1933. Dinoflagellatae (Peridineae) in monographischer Behandlung. In: Rabenhorst L (ed), Kryptogamen-Flora von Deutschland, Österreich und der Schweiz, pp. 1-617. Akademische, Leipzig.

Schütt F. 1895. Die Peridineen der Plankton Expedition, I. Teil. Studien tiber die Zellen der Peridineen. Ergebnisse der Plankton-Expedition Humboldt-Stiftung 4: 1-170.

Steemann Nielsen E. 1934. Untersuchungen über die Verbreitung, Biologie und Variation der Ceratien im südlichen stillen Ozean. Dana Report 4: 1-67.

Stein FR von. 1883. Der Organisms der Infusionsthiere, 31 pp. Wilhelm Engelmann, Leipzig.

Tang DL, BP Di, G Wie, IH Ni, IS Oh \& SF Wang. 2006. Spatial, seasonal and species variations of harmful algal blooms in the South Yellow Sea and East China Sea. Hydrobiologia 568: 245-253.

Taylor FJR. 1976. Dinoflagellates from the International Indian Ocean Expedition. A report on material collected by R/V «Anton Bruun» 1963-1964. Bibliotheca Botanica 132: 1-234.

Venrick EL. 1982. Phytoplankton in an oligotrophic ocean: observations and questions. Ecological Monographs 52: 129-154.

Wood EJF. 1968. Dinoflagellates of the Caribbean Sea and adjacent areas, 143 pp. University of Miami, Coral Gables. 